\title{
THE FRONTLINE AS PERFORMATIVE FRAME: AN ANALYSIS OF THE UK COVID CRISIS
}

\author{
Sara Farris, Nira Yuval-Davis and Catherine Rottenberg
}

\begin{abstract}
In this paper, we examine the multiple significations of the "frontline" metaphor in the UK during the first ten months of COVID-19. We argue that the term "frontline" has operated as a performative frame, which has helped to produce the very notion and the materialization of the "COVID-19 frontline" and keyworkers. Showing how the UK government has repeatedly cited this metaphor, we outline the contradictory effects it has generated through an interplay of hyper-visibility and opaqueness. The frontline metaphor has been used to justify the government's injection of massive amounts of public money into the economy, render hyper-visible workers who had previously been invisible, whilst generating a sense of civic responsibility. Simultaneously, however, the metaphor has created a smokescreen for corrupt practices, deflecting attention away from resourcestarved health and social care infrastructures and intensifying forms of "everyday bordering" and "everyday racism" that deepen structural injustices in the UK.
\end{abstract}

Keywords: frontline; metaphor; keyworkers; COVID-19; performative frame; UK; national belonging

\section{The Frontline as a Performative Frame: An Analysis of the UK COVID Crisis}

On 17 March 2020, in his second ever public coronavirus briefing, UK Prime Minister Boris Johnson stated that, "we must act like any wartime government . . . [T] his enemy can be deadly but it also beatable."' Just a few days later, on 23 March, Johnson officially announced the imposition of emergency measures, including an unprecedented national lockdown, urging the country to stay at home. He concluded his speech by thanking "everyone . . . from the supermarket staff to the transport workers, to the carers, to the nurses and doctors on the frontline. But in this fight... each and every one of us is directly enlisted." 2 In the months that followed, the government would repeatedly invoke military imagery to describe the country's fight against the spread of COVID-19, whilst the

Equal contributions by Sara Farris, Goldsmiths University of London, Nira Yuval-Davis University of East London, and Catherine Rottenberg, University of Nottingham. Catherine Rottenberg would like to thank the Leverhulme Trust Research Fellowship (REF 2020-639) for helping to fund this research. 
frontline metaphor was taken up by a range of actors and media to describe not only NHS medical workers but all "keyworkers," whose labour was considered vital for society's day-to-day functioning and very survival. ${ }^{3}$

Johnson's early coronavirus briefings vividly highlight the ways in which the virus has been construed not merely as a serious health threat but also as an enemy of the British people, with keyworkers portrayed as brave - even if conscriptedsoldiers willing to sacrifice their own well-being for the good and protection of others. The invocation of military metaphors clearly served to stoke national unity at a time when the country was perceived to be under attack. Moreover, as the wartime and nationalist rhetoric continued, the UK government began taking dramatic steps: unrolling a massive government furlough scheme and economic stimulus package, whilst encouraging widespread public support for "frontline" keyworkers, exemplified in the popular weekly "clap for carers" (Wood and Skeggs 2020).

Given that the UK has, for decades, been at the forefront of implementing neoliberal policies, the move to increase public spending led some commentators to suggest that we were witnessing an unexpected shift to a more progressive economic agenda (e.g. Steward 2021). Moreover, as non-medical care and other "low-skill" workers were reframed as frontline heroes saving lives, their historic social invisibility and low wages were decried, and in certain circles there were growing demands to reverse the labour hierarchy that has traditionally positioned them at the bottom of the economic pecking order (Bergfeld and Farris 2020). War metaphors - and particularly the notion of frontline heroes - has also been used by the government not only as a call for unity (Fotherby 2020), but as a way of attempting to strengthen community cohesion and civic duty across different segments of British society.

In this paper we examine the multiple significations of the frontline metaphor in the UK context during COVID-19, arguing that the metaphor has helped to produce an atmosphere of extraordinariness, facilitating the introduction of emergency measures whilst also infusing a sense of solidarity and civic responsibility across the population. The positive public response to the call for civic responsibility was particularly pervasive during the first national lockdown, not only muting public opposition to the government's missteps, ongoing U-turns and inconsistent policies, but also helping to deflect attention away from a series of profoundly contradictory economic and social processes and their material consequences. The frontline metaphor, thus, has operated as a "performative frame," spawning a range of effects - and affects - whilst simultaneously justifying and obfuscating often opposing narratives and on-the-ground developments that have taken place since March 2020. The repeated iteration and citation of the term "frontline" has, in other words, helped to produce the very notion and the materialization of the "COVID-19 frontline" alongside an array of categories such as "keyworkers" and has bolstered notions of a unified national "we." 
After first excavating the metaphor of the frontline, we outline what its reiteration in the context of post-COVID-19 Britain has engendered, and how it has been deployed to create a sense of exception that set the stage for the introduction of emergency measures. We then show how the "frontline" was wielded as a catchphrase for the government's ostensible change of direction in economic and social terms, namely, from a market-led to a more state-led economy, and from an atomized society to a more unified one. The repeated citation of the metaphor, we argue, has helped the Johnson administration justify a big-state approach and apparent shift in priorities - from "economic growth" to "saving lives" — whilst enormous amounts of taxpayers' money were transferred to corporations and private individuals, often without oversight or public tenders. This was enabled through the passing of coronavirus legislation which deprived the parliament of much of its power of scrutiny.

The frontline metaphor as frame has, in other words, helped to exclude from view and thus conceal the disastrous neoliberal and crony capitalism that has continued unabated and even exacerbated during the pandemic. Simultaneously, the metaphor has undoubtedly generated a new appreciation of certain workers, holding out the promise that traditional labour hierarchies could eventually be dramatically modified. Yet, on the ground, the marketization of key services intensified during the pandemic's first ten months, and it now appears that the government's mobilization of support for the frontline has obfuscated the fact that working conditions for the vast majority of keyworkers have not only remained poor and unsafe but in many cases deteriorated even further. Given that they have led to mass human suffering and countless unnecessary deaths - particularly of disadvantaged groups - we understand these neoliberal policies and cronyism as state crimes (Green and Ward 2004). Finally, we explore how the frontline metaphor has been cited to foster civic duty and responsibility, which has blurred the faultlines between different conceptions of citizenship and national belonging. The frontline revived an ultimately ambiguous national "we" that helped to deflect increasing divisions in the wake of Brexit. This has been most evident in the way in which migrant keyworkers have been held up as national heroes at the same time that they have been deemed dispensable in the post-Brexit landscape. We conclude by pointing to some further developments in the performative citation of the frontline, namely, its recent uptake by the frontline workers themselves to highlight their working conditions, which can be understood as challenging and even subverting some of the metaphor's earlier performative effects.

\section{The War Metaphor of the Frontline}

A brief investigation into the historical emergence of the word "frontline" reveals, perhaps not surprisingly, that the term originated as a war metaphor in English, 
signifying a "field of operations in contact with the enemy." However, over the course of the 20th century, its meaning has shifted and expanded so that today it is used in a variety of contexts and fields - from business and management (e.g. Rosenthal 2004) and museum studies (e.g. Balogun et al. 2015) to social work (e.g. Jones 2001). Thus, in addition to military references, the term "frontline" now describes workers directly engaged with customers, clients, patients or participants in a particular activity. The term also refers to ideas that are in the vanguard, such as "frontline research" or even "frontline fashion" (Poole 2020). In contemporary parlance, then, the frontline has come to depict someone or something at the forefront of some area and/or in close proximity with someone else, but not necessarily in a situation of hostility or danger. Despite this variety of usages, during the pandemic the term "frontline" has clearly maintained its original association to war and the battlefield. Both the UK government and the media have repeatedly called frontline workers "heroes," "fighting" indefatigably against an invisible but common enemy. This multifaceted dimension of the military metaphor of the frontline has been captured by Yasmin Gunaratnam, stating that it "blurs willingness, duty, coercion, vulnerability and protection" (Gunaratnam 2020).

What interests us in this paper, however, is less what war metaphors mean or the contexts in which they have historically been used. Rather, we explore the way in which the metaphor has helped to frame the events of the past year as well as the material and affective effects the frontline metaphor has generated in the specific context of COVID-19 in the UK. Metaphors, after all, are not neutral ways of perceiving and representing reality, but actually carry out social and cultural work as they highlight "some aspects of the target and background others, facilitating different inferences and evaluations" (Semino 2021: 2; Lakoff and Johnson 2008; Sontag 2001). War metaphors used in the context of illness, for instance, evoke the need to eradicate the disease, while pushing to the background the possibility of learning how to live with it: "As such, in communication, metaphors are important rhetorical devices, especially when the aim is explanation or persuasion." (Semino 2020: 2).

Additionally, as scholars such as James Fotherby (2020) point out, administrations around the world have chosen to anthropomorphize COVID-19 as a common "invisible enemy" and invoke military metaphors for two main and interrelated reasons. First, the analogy between war and health has a very long history, as military metaphors have historically been deeply embedded in medical discourse and vice versa (Bell 2012; Sontag 2001). The two fields actually operate according to a similar logic, with war-makers primarily concerned with saving the nation, whilst health professionals, and particularly those dealing with epidemiology and public health, are concerned with saving the social body (Gordon 2021). Second, and most obviously, military metaphors and comparisons are often used in times 
of crisis by governments to drum up a "nationalistic response from civil society, mobilising all in a common effort against a common enemy." (Fotherby 2020).

Metaphors thus create what scholars call "framing", shaping the way in which the public thinks and feels about issues and how we address them (Semino 2020; Sontag 2001). The war metaphors invoked by the UK government during COVID-19 must therefore be understood as performative iterations, which, in their very utterance, enact what they enunciate while simultaneously producing a series of effects and affects in and through their repetition within the public arena (Butler 1990, 1993, 1997, 2009). These effects and affects can, of course, be unexpected and even contradictory, as well as change over time. By repeatedly invoking the metaphor, the UK government has helped to produce-both the notion and the materialization - of a COVID-19 frontline as part of the public imaginary, drawing on a longer history of similar iterations and ritualizations, thus framing the situation as exceptional. We also suggest that the frontline metaphor has managed, at least to some degree, to mobilize the population during this time of crisis and help to legitimize the introduction of emergency measures that undermine democratic processes. Yet, as time passes-just like in war-the population is likely to grow restive and resist some of the restrictions imposed upon them. In the pandemic's early days, the notion of the frontline and other war metaphors did help the government to keep people on high alert and united behind the national effort. During the second and particularly the third national lockdown, these same metaphors appear to have lost at least some of their mobilizing power. Concurrently, they have been increasingly taken up by frontline workers themselves to highlight their everyday working conditions and even critique government inaction.

This article is particularly interested in exploring the "contradictory" performative effects of the frontline war metaphor during the first ten months of the pandemic in the UK. One of these effects has been to render opaque the ways in which the government has actively exacerbated inequalities on both the economic and social spheres, in part through passing "The Coronavirus Act," that has been used to bypass Parliament. The framing of national financial institutions as if they too are part of the frontline, has, moreover, obscured how corruption, cronyism and a deadly disregard for the vulnerable - namely, a series of state crimes - have informed much of the UK government's response to the pandemic (Gordon and Green 2021). Thus, in this paper we do not investigate what the metaphor of the frontline does to any particular individual or group of individuals, nor do we analyse how the metaphor of the frontline as a performative act interpellates individuals into assuming a certain subject position. Rather, we outline how the frontline metaphor has operated as a performative frame for political discourse, how the government has repeatedly cited this metaphor to respond to the current crisis, and 
the contradictory effects it has generated as well as concealed through an interplay of rendering certain features of the crisis hyper-visible and others opaque.

\section{The Metaphor of the Frontline in the Economic Field}

At the level of the economy, the frontline has served as a performative frame that has helped to promote a particular narrative regarding fundamental shifts in the UK government's policies and priorities. This frame has been produced and maintained, in large part, through two different but interrelated rhetorical tropes. First, the government and various financial institutions have declared themselves to be on the frontline as they have tried to save the economy from disaster by injecting a massive amount of money into the system. Second, workers who had previously been stigmatized and paid very low wages have been consistently positioned and portrayed as frontline heroes.

As mentioned, the government's new economic policy, which seemingly reversed ten years of austerity, alongside the lionization of all "keyworkers," has been read as potentially challenging the reigning neoliberal dogma of fiscal austerity as well as the division of labour between highly valued, highly skilled and low-paid, low-skill occupations. In both cases, the war metaphor of the frontline figures prominently as a performative framing to aid in the creation of an atmosphere of extraordinariness, which, just like in times of war, requires an army of generals (the government) and soldiers (the workers) who are deployed in close proximity to the enemy. It is also this exceptional situation that justifies emergency measures and the suspension of the normal course of things (Schmitt 2005)—whether in politics, the economy or the social landscape.

\section{The Frontline State}

Concerning the first rhetorical trope, Boris Johnson's government as well as national financial institutions have mobilized the frontline metaphor to describe their own position as ground zero in the battle against COVID-19. The UK government has repeatedly described itself as protecting the people, and during the early months of the pandemic, as offering one of the most generous bailout measures in decades. ${ }^{5}$ The Chancellor of the Exchequer, Rishi Sunak, has insisted again and again that he is defending the nation against mass unemployment and other devastating financial losses which the invisible adversary has threatened to unleash. ${ }^{6}$ Such declarations echo those of the Bank of England, which has made reference to the frontline to depict its essential role during the pandemic, describing its new low-rates policy as helping "UK businesses and households manage through an economic shock that could prove sharp and large." 
By framing themselves as on exceptional war-time footing - and, more specifically, as the first line of defence against a lethal common enemy - the Johnson administration and these usually pro-austerity financial institutions clearly aimed to garner public support and (re)style themselves as protectors of the people. Indeed, through its insistence that the government is prioritizing "saving lives" and putting people before profit, the frontline rhetoric attempts to cultivate and infuse a sense of solidarity and positive affect (Ahmed 2010) across the population while deflecting attention from misguided policies and mismanagement of the crisis. Simultaneously, it has enabled the government to design and implement more welfare-oriented policies at great speed, policies that would have been anathema to its own party members and many of its voters just a few months before the pandemic hit.

Scholars and commentators from the left, centre, and the right have indeed interpreted the mobilization of the state and financial institutions to make cash available for employers as a potential opening for a redistributive agenda that could well signal the end of neoliberalism and the (re)emergence of a more equitable welfare state. This interpretation was particularly prevalent during the first national lockdown when the scale of the government stimulus package was revealed. A 3 April editorial in the Financial Times, for instance, stated that "Governments will have to accept a more active role in the economy. They must see public services as investments rather than liabilities and look for ways to make labour markets less insecure. Redistribution will again be on the agenda." (Financial Times 2020). From a similar perspective, The Economist featured a programme asking whether COVID-19 would kill globalization as we know it. ${ }^{8}$ On the other side of the political spectrum, the left-leaning economist Alfredo Saad Filho argued that: "With the pandemic, Conservative sermonizing about the imperative of 'fiscal austerity' was obliterated by the evident capacity of the state to create money from nothing and deliver salvation to selected sectors." (Saad Filho 2020: 481). The European Sociological Association's journal has also featured a series of articles analysing the (re)emergence of "state capitalism" in many Western economies as the development that could put the future of neoliberalism into question. ${ }^{9}$

These examples demonstrate that initially the crisis generated by the pandemic managed to produce a moment of cross-political consensus - or what we call a performative effect — challenging the accepted and dominant notion that markets and not states are better suited to run the economy. This is true, even as commentators from different sides of the political spectrum interpreted this shift in different ways and from very different perspectives. For a certain period it seemed that the state had been called upon to dramatically invest in public infrastructures and services and save the nation from the invisible enemy, raising the question of whether the UK could ever return to austerity or pre-pandemic policies of increased 
deregulation, privatization and the outsourcing of public services. By positioning itself as on the frontline in the battle against COVID-19, the government appeared to revive the notion (and the actions) of the "big state," which prompted, in turn, a range of scholars and commentators to suggest that we may well be witnessing a fundamental policy shift, with some even preparing an elegy for neoliberalism.

However, not only have more recent declarations and developments - such as the government's much publicized decision to put a pay freeze on most publicservice workers - highlighted that these death knells were premature, but, perhaps even more importantly, they are also premised upon a widely held misconception about the role of the state under neoliberalism. Most commentators understand neoliberalism as the reign of the free market and the demotion of the state to the role of supporting character at best, or spectator at worst. Yet, as Dardot and Laval (2014) aptly remind us, the "free-market" is a myth far removed from actual practice. Such a myth conceals the fact that neoliberalism aims not so much at the retreat of the state, but rather the transformation of state action "by making the state itself a sphere governed by rules of competition and subject to efficiency constraints similar to those experienced by private enterprises." (Dardot and Laval 2014: 216). Thus, whilst it is true that the "producer state" has certainly been dismantled by the privatization of key public services and companies, the state has not - and, in fact, has never - lost its regulatory economic power (see also Foucault 2008; Brown 2015, 2019). Rather, state power has been restructured through the importation of competitive market rules into the public sector, "to the point of conceiving the exercise of government power in accordance with the rationality of the enterprise." (Dardot and Laval 2014: 218).

This misconception becomes more glaring when examining how, precisely as the UK government and many commentators were touting the injection of huge amounts of public money into the economy, much of this money was being siphoned off to private companies and corporations. The British Medical Association (BMA) has documented how during the COVID-19 outbreak, the UK government outsourced vital services to the private sector in its response to the virus, particularly in England. ${ }^{10}$ Rather than adhering to competitive market rules, however, billion-pound contracts were given without a public tender or any kind of oversight. The Good Law Project, for its part, has exposed how Johnson's government has facilitated an increasingly well-documented litany of corrupt practices under The Coronavirus Act 2020. Investigative work by this and other groups has shown, in some detail, the "special pathways" by which cronyism and clientelism have advanced the interests of private corporations at the expense of public health (Good Law Project 2020). Thus, not only has the government poured public money into private companies for a range of COVID-19-related services, equipment and materials, namely, PPE procurement, the establishment of COVID-19 testing 
centres and laboratories, developing the track and trace strategy and staff recruitment, but these contracts have been awarded to the private sector under special pandemic powers that circumvent normal tendering processes. Even more shockingly, the chosen companies have been accused of mismanagement of public monies in the past, thereby casting serious doubt on their suitability for such crucial operations in the first place. ${ }^{11}$ Tragically, the past months have proven that these same companies' strategies in key areas such as PPE supply, track and trace, and testing have also been mired in scandal and failure, costing an unknown number of people their lives, whilst wasting billions of pounds of public funds that might have been invested in improving health care infrastructure. Yet, to date, there has been little organized public outrage for what should be considered state crimes. ${ }^{12}$

In many ways, then, the COVID-19 pandemic can be understood as intensifying key contradictions inherent within neoliberalism, such as the central role of the state in facilitating deregulation and privatization and moving taxpayers' money from public welfare to corporate welfare. The frontline metaphor as a performative frame has precisely served to obfuscate these contradictions, even as they have deepened over the past months. Its repeated citation and its ensuing hypervisibility have enabled the government to justify initial big-state interventions and to situate itself as defender of the well-being of the people, whilst concurrently overriding oversight processes and public tenders, which has allowed the Johnson administration to siphon huge amounts of public money to corporations and individuals closely aligned with the Tories.

\section{The Frontline Workers and Labour Relations}

In terms of the rhetorical trope of frontline heroes, since March 2020 we have also seen how a wide range of workers, from agricultural laborers through supermarket employees, waste collectors and cleaners to non-medical care workers, have been recast as "essential" and "key" and depicted-alongside the government and financial institutions - as a crucial part of the first line of defence against the invisible enemy. The public glorification of these often low-paid and low-skilled jobs has undoubtedly rendered these workers much more visible to the public than in the past. Alongside the much-publicized weekly clap for carers, there have been countless media stories featuring frontline workers: from the BBC's series of "portraits of NHS frontline 'heroes"'13 through Vogue UK's cover page images of non-medical "frontline workers" 14 to the proliferation of homemade posters "thanking frontline heroes" in public and private spaces across the country. Crucially, this has also meant that the disproportionate presence of BAME people - and often BAME women ${ }^{15}$ - working on the frontline in the health, care and public services sector has been rendered much more visible. There seems to be little question, then, that the use of the frontline to describe the position of these 
workers has helped to generate a newfound appreciation for and visibility of these life-maintaining workers and has led to a call—again, from left to right-for a reassessment of their salaries and working conditions, or at least for rewarding their efforts in the fight against the virus.

In late 2020, for instance, the Financial Times carried a number of articles suggesting the need to compensate frontline key workers through higher wages and more secure contracts. ${ }^{16}$ On the political scene, the Liberal Democrats have called for frontline health staff to receive the same £29-a-day "active duty" bonus as the armed forces, whilst Labour leader Sir Keir Starmer has called for a "reckoning" for keyworkers once the crisis has passed, claiming that keyworkers have "often been overlooked [and] underpaid." 17 Even more conservative-leaning media venues, such as the Daily Mail and Daily Telegraph, have called for the government to reward frontline workers with cash bonuses or similar one-off rewards to thank them for their life-saving work during the pandemic.

In addition, a number of scholars have suggested that the recognition of lowskill workers as "keyworkers" has led to an "unprecedented shift of the occupational prestige of some lower status workers." (De Camargo and Whiley 2020: 11). A poll carried out by the Fawcett Society in May 2020 provides some evidence that there has indeed been a shift in public opinion, finding that the vast majority of people interviewed supported an increase in income tax to fund a pay raise for care workers. ${ }^{18}$ Meanwhile a YouGov poll found that keyworkers themselves also feel more appreciated than before the pandemic. ${ }^{19}$ Thus, not surprisingly, and similar to the reactions to the massive public spending on providing furloughs for workers, the newfound public visibility and appreciation for frontline workers has also been read as potentially facilitating and even mandating a new government course, one that challenges the traditional division of labour hierarchy. After all, COVID-19 has laid bare in dramatic ways that society simply cannot function without the crucial labour that keyworkers carry out on a daily basis.

It seems clear that the metaphor of the frontline has rendered this disproportionately BAME and female migrant workforce highly visible. At the same time, however, the widespread praise of these frontline heroes has not been followed by a similar commitment to increasing their wages or improving their working conditions. The opposite seems true. In November 2020, Chancellor Rishi Sunak announced a pay freeze for 5 million public sector workers in a move that has been described as "grinding frontline workers down," ${ }^{20}$ given that a pay freeze is, in effect, a pay reduction over the longer term. Thus, while increased public recognition and symbolic appreciation for these previously devalued jobs has been a central feature of the unfolding COVID-19 crisis, concrete improvements in the working conditions of frontline workers have simply not materialized. This has been underscored, yet again more recently, as the UK became the first country in Europe to authorize the 
rollout of the coronavirus vaccine. Yet, the very same keyworkers lionized as frontline heroes were not on the frontline to receive the first doses. Precisely by rendering keyworkers hyper-visible and showering them with symbolic public praise, the frontline metaphor has deflected attention away from continued government neglect of their working conditions and low wages.

\section{The Frontline and the National "We"}

Finally, in terms of the social landscape, the metaphor of the frontline hero has helped to generate an ostensibly more inclusive national "we." The dominant government mantra, especially in the pandemic's early days was that "We're all in it together." During the first national lockdown, Johnson very self-consciously contradicted former Conservative Prime Minister Margaret Thatcher's now (in)famous statement that "there is no such thing as society." In a much-publicized video released in late March 2020 while Johnson was self-isolating, he claimed that "One thing the coronavirus crisis has already proved is that there really is such a thing as society." Again, the emphasis was that "We are going to do it, we are going to do it together." 21 Implicit in Johnson's repeated invocation of the frontline and his rallying cry to the nation during these early coronavirus briefings was that individuals are interdependent, embedded in communities, and that the "we" needed to be as capacious as possible if the invisible enemy were to be vanquished. The new slogan Johnson used when he began easing lockdown measures in May 2020, namely, to "stay alert" was also clearly directed to this expansive collective: "We must stay alert. We must continue to control the virus and save lives."22

The government's acknowledgement of people's interdependence and its repeated calls for togetherness and for a capacious British plurality clearly appealed to ideals of community. Johnson has insisted, time and again, that, "Each and every one of us is now obliged to join together." ${ }^{23}$ In this way, the current administration attempted to cultivate feelings of solidarity and civic duty, whilst connecting the home front with the frontline into a united "we." Through the construction and glorification of COVID-19 keyworkers as generic frontline heroes, keeping us safe yet needing our support in order to fight the common enemy successfully, a symbolically inclusive "we" was generated, redrawing the lines of those who could belong to the nation. Indeed, all essential workers - ostensibly even non-UK migrant ones - were symbolically recast as part of the civic and national "we."

The metaphor of the frontline has, in other words, managed to loosely fuse two competing notions of imagined national communities (Anderson 1991), blurring their fundamental incommensurability and providing an "inclusive" framing. The first conception of the "we" implies a communitarian-civic community in which "we" are all those who live in Britain and are affected by the COVID-19 pandemic, 
regardless of citizenship status. The second "we" includes only those who are British nationals and thus legally entitled to access available public goods. The first mobilizes the population via widespread solidarity, echoing the inclusive "we" conjured up in Johnson's early briefings; the second mobilizes an exclusive "we" through divisive social policing and "everyday bordering," which refers to the processes and practices by which citizens are "recruited" to become unpaid and untrained border guards, and by which all British citizens have a legal duty to check and confirm the legal status of anyone who looks or sounds as if they "do not belong" (Yuval-Davis et al. 2019). ${ }^{24}$ The construal of all frontline workers as "national heroes" and an expansive "we" who are called upon to support the national effort has obfuscated the difference between these two conceptions of the "we" and has helped to prevent any significant public discussion about the fact that so many of these essential workers are not British nationals and that, in a post-Brexit landscape, many may be denied the right to remain in the UK. It has also, we suggest, helped to render much less visible the xenophobic and discriminatory policies informing the exclusive "we," policies that have continued to be implemented throughout the pandemic period.

In the pandemic's early days, the UK witnessed a massive outpouring of calls for solidarity from within civil society, with countless local groups of mutual aid sprouting up across the country. The slogan "stay alert" and be responsible to avoid further spreading of the virus appeared to resonate as a call for expansive community solidarity rather than individual accountability. By June 2020, for instance, there were thousands of community-based and volunteer mutual aid groups functioning all around the UK; ${ }^{25}$ their objective, according to the COVID-19 Mutual Aid UK website has been to "coordinate care efforts for people who are self-isolating, especially if they are part of a more at risk demographic including the elderly, disabled and people with other pre-existing health issues." The emphasis has been on "community care" and support for the most vulnerable ${ }^{26}$ — namely, an inclusive "we." In addition, in the wake of the government's ostensible shift in direction away from austerity to "saving lives" and putting people over profit, there was a renewed push by various organizations, such as the Migrant Rights Network to end many of its discriminatory policies around migration. Pressure was applied on the Home Office to allocate public funds to those who have no legal rights of residency and to stop their deportations. ${ }^{27}$ The performative construction of certain workers as frontline heroes also appears to have caused a shift in public opinion more broadly. Parallel to the polls indicating that the public supports measures that would increase care workers' pay, some recent polls also indicate that the majority of people interviewed now support granting citizenship to migrant "frontline heroes." 28

Yet, in similar fashion to the positioning of the government on the frontline, the invocation of the metaphor here, too, has also deflected attention from the ways in 
which discrimination and "everyday bordering" has continued unabated during the pandemic. This kind of harassment and policing, moreover, has not only continued to shape the lives of so many frontline workers, as well as migrant and racialized populations more generally, but during the pandemic, the UK witnessed more rather than less scrutiny around people's legal citizenship status (Meier and Dona 2021; Gardner 2020). At the very same time as keyworkers were being repeatedly praised as national heroes and as an essential part of an inclusive "we," a whole set of policies, first adopted by the then Home Secretary Theresa May to encourage those who "do not belong" to leave the country, continued and were even accelerated.

Throughout the pandemic, for instance, NHS workers themselves have continued to be involved in everyday bordering practices by checking legal entitlements of those who ask for NHS services, charging them fees and reporting to the Home Office the personal details of those who require their services. ${ }^{29}$ Furthermore, just two weeks into the first lockdown, the Home Office published the guidance for the new post-Brexit points-based immigration rules on its website. ${ }^{30}$ According to these guidelines, the same workers being hailed in public as national heroes were constructed in policy as unskilled and occupying low-paid work and could therefore be deported from the UK at any time. Nothing illustrates this contradiction better than the news that the family of a doctor who became paralysed as a result of catching COVID-19 while working on the "frontline" has been threatened with deportation while he is still fighting for his life in an intensive care unit. ${ }^{31}$ Even more recently, it has come to light that a second reading of Parliamentary Immigration Bill that would allow migrant doctors and other healthcare professionals - namely, those frontline heroes protecting lives - the right to remain in the UK indefinitely after Brexit, has been postponed. At the time of writing, it is not clear when the next reading of the bill will take place.

The repeated citation of a capacious national "we" has thus rendered opaque the distinction between an inclusive and exclusive "we," concealing the on-the-ground reality that many frontline workers are not British nationals, some of them are not even working in the UK legally, and too many of them are still under constant threat of deportation. They have been glorified as heroes but are simultaneously deemed disposable - very similar, in fact, to soldiers on the battlefield. The performative framing of the frontline has helped to engender these contradictory effects.

\section{Conclusion}

Over the past ten months, the frontline metaphor has done a number of things in the UK. As we have detailed, not only has the repetitive citation of the metaphor helped generate an atmosphere of extraordinariness, but it has produced the very notion and the materialization of a frontline. As a performative frame, the frontline 
metaphor has helped to justify the Conservative government's injection of massive amounts of public money into the economy; it has rendered hyper-visible a whole class of workers who had previously been invisible, ascribing value to the labour that they perform; and, finally, it has also generated an inclusive "we," uniting "frontline" with home front, which has infused the social body with a sense of civic responsibility and solidarity. Some of these developments are historic, such as the very public recognition that the labour performed by keyworkers-from supermarket stockers to public transportation and social care workers-is absolutely central to society's survival; others, such as the stimulus package and furlough scheme, are certainly extraordinary and have, without doubt, kept many people afloat financially during the crisis.

At the same time, the metaphor has been used by the government to facilitate processes that directly counter these progressive developments and to commit a series of state crimes. It has concealed and thus provided a smokescreen for the siphoning off of massive amounts of public funds to private companies with no public oversight; it has deflected attention away from resource-starved health and social care infrastructures. And it has served as a cover for intensifying forms of everyday bordering and "everyday racism" (Essed 2008). ${ }^{32}$ In sum, the metaphor has produced a particular frame of exceptionalism, highlighting the boldness of the government as well as the heroism of frontline workers, whilst obscuring the various and very concrete ways in which structural injustices have profoundly deepened during COVID-19. As Lisa Bowleg puts it, "Although seemingly innocuous and often well intentioned, the phrase 'we are all in this together' reflects an intersectional color and class blinding that functions to obscure the structural inequities that befall Black and other marginalized groups, who bear the harshest and most disproportionate brunt of anything negative or calamitous." (2020: 917). ${ }^{33}$

However, performatives are, as Judith Butler has long argued, "excitable", subject to unexpected and even subversive reiterations. Precisely because performative speech acts - and in our case, performative frames - are produced and maintained through iteration, they do not act in deterministic ways (Butler 1997). The performative frame of the frontline is dependent on its reiteration for its "sustenance," and thus there is always the possibility that the frame will be taken up in unpredictable and potentially subversive ways. In this sense, then, performatives are "constantly breaking with the contexts delimited as their 'conditions of production'. This break, however, is nothing other than a series of significant shifts that follow from the iterable structure of the performative." (Butler 2009: 168-9).

At the time of writing, the UK is experiencing its third government-mandated national lockdown. This has meant that, following a number of months in which the frontline metaphor was somewhat in retreat - in large part due to the easing of lockdown measures in the summer and autumn of 2020 and the return to some 
semblance of "normal" - it has resurfaced. The COVID-19 frontline, after all, can only be effectively conjured up and materialized when the social body is framed as being under immediate threat by the invisible enemy. In the wake of surging infection rates and deaths in the winter of 2020/21, the threat had rebounded. Workers on the frontline have once again been in the public spotlight, since, in contrast to the rest of the population, they continue to go out to work every day in order to ensure that the rest of us are safe and that society continues to function, or to put it in Gunaratnam's words, they are those standing "between us and premature death" (Gunaratnam 2020). As time passes, a number of further developments in the performative invocation of the frontline have occurred, such as the inclusion of more workers - like teachers and university lecturers - in the definition of keyworkers. By way of conclusion, we would like to outline one particular development that underscores how performative framings can be cited in ways that potentially challenge their original effects and affects.

More specifically, in the initial months of the national lockdown, many NHS workers and other keyworkers seemed to resent being labelled heroes and resisted the metaphor of the frontline. In much of the early media coverage, for example, many workers positioned on the frontline insisted that they were not heroes but simply doing their job. ${ }^{34}$ As one doctor put it in May 2020: "I don't work on the frontline because there isn't one. I'm not in the army and we aren't engaged in military combat." ${ }^{35}$ Yet, with the passing of time, the metaphor of the frontline has increasingly become part of UK common sense, and more and more keyworkers - and particularly NHS staff, given the increased stress on the healthcare sector-seem to have actively embraced the frontline metaphor to describe their role. For instance, the Department of Military Mental Health at King's College London recently prompted a public discussion on the seriousness of the challenges faced by NHS frontline workers, drawing a parallel between NHS ICU workers and soldiers on the frontline of a battle. According to their study, the levels of post-traumatic stress disorder (PTSD) among a sample of ICU NHS workers during the pandemic were higher than those to be found among deployed soldiers in the battlefield. As the leading researcher, Professor Neil Greenberg underscored, "The fact that NHS staff appear to be suffering more than combat troops is quite worrying." ${ }^{36}$ Given that he explicitly spoke about a "frontline psychiatry" to help alleviate the threat of "moral injury" faced by NHS staff in their line of duty, alongside his demand for better "psychological PPE" for NHS staff, Greenberg's comparison of NHS workers to "soldiers" received wide media coverage. ${ }^{37}$ Moreover, several NHS trusts across the country now host blogs or webpages describing their "life on the frontline." 38 Similarly, the NHS called the pool of medical students volunteering or helping in hospitals in the last few months as joining the "NHS Army." 39 
In short, what we have witnessed is not only that the frontline metaphor is now being explicitly used in increasingly militaristic terms to describe essential workers, particularly NHS staff, but also that more and more keyworkers themselves are adopting and mobilizing the performative framing of the frontline to highlight their often difficult — and "war-like" - everyday working conditions. Whether or not this self-identification as frontline workers is meant to critique the government and its policies is not always clear, but what the adoption of this metaphor inevitably does do is to expand the possible venues for exposing the structural challenges confronting so many of these workers. And given the historic visibility and public appreciation of keyworkers at this time, these venues certainly have the potential for generating and even mobilizing a more organized public outcry at the oppressive and exploitative structures that continue to shape British society.

The war metaphor of the frontline as a performative framing thus seems to have undergone some important shifts in the UK since the start of the pandemic. It emerged in March 2020 as a performative framing that generated solidarity and public mobilization whilst concealing contradictory economic and social processes; ten months later it was being used by keyworkers themselves to highlight the war-like conditions of their workplaces. Yet, at the very moment the metaphor is being retooled and adopted by the workers themselves to expose structural issues, it appears to be losing some of its power to mobilize the population-either to generate solidarity or to stay alert. ${ }^{40}$ There seems little doubt, then, that as the pandemic continues to ravage the UK, and indeed, the world, the consequences of the frontline as a performative framing will continue to unfold.

\section{Notes}

1. https://www.gov.uk/government/speeches/pm-statement-on-coronavirus-17-march-2020 (accessed 14 February 2021).

2. https://www.gov.uk/government/speeches/pm-address-to-the-nation-on-coronavirus23-march-2020 (italics added and accessed 14 February 2021).

3. The government definition of "keyworkers" shifted over the first ten months of the pandemic. For the current definition, see https://www.gov.uk/government/publications/coronavirus-covid19-maintaining-educational-provision/guidance-for-schools-colleges-and-local-authorities-onmaintaining-educational-provision (accessed 14 February 2021).

4. See https://dictionary.cambridge.org/dictionary/english/front-line; and https://www.theguardian.com/books/2020/apr/16/frontline-is-it-misleading-to-apply-military-metaphors-to-medicine (accessed 14 February 2021).

5. According to the Institute for Fiscal Studies, the UK government borrowing this year is likely to be the largest share of national income in peacetime, surpassing those seen at the height of the global financial crisis in $2009-10$ when borrowing reached $10.2 \%$ of national income. See https://www. ifs.org.uk/publications/14845 (accessed 14 February 2021). 
6. Rishi Sunak has been repeatedly described as the most popular Chancellor in decades. See e.g. https://www.theguardian.com/commentisfree/2021/jan/22/rishi-sunak-thrived-pandemic-popularity (accessed 14 February 2021).

7. See https://www.bankofengland.co.uk/news/2020/march/boe-measures-to-respond-to-the-economicshock-from-covid-19 (accessed 14 February 2021).

8. https://www.youtube.com/watch? $v=$ KJhlo6DtJlk (accessed 14 February 2021).

9. https://www.europeansociologist.org/issue-45-pandemic-impossibilities-vol-1/political-economy-and-politics-\%E2\%80\%93-covid-19-critical-political (accessed 14 February 2021).

10. https://www.bma.org.uk/media/2885/the-role-of-private-outsourcing-in-the-covid-19-response. pdf (accessed 14 February 2021).

11. See e.g. https://www.nytimes.com/interactive/2020/12/17/world/europe/britain-covid-contracts. html (accessed 14 February 2021).

12. Drawing on Green and Ward (2004), we define state crime not only as more "overt agent-driven acts of state crimes such as genocide, torture and grand corruption" but rather as including neoliberal austerity measures that have caused mass suffering and countless deaths and, more generally, "human rights violations perpetuated by states through both over-reach and under-reach in structural terms" (Green and Ward 2004: 7).

13. See https://www.bbc.co.uk/news/uk-england-york-north-yorkshire-52664628 (accessed 14 February 2021)

14. See https://www.vogue.co.uk/news/article/keyworkers-july-2020-issue-british-vogue (accessed 14 February 2021).

15. Although beyond the scope of this paper, more and more research has underscored that the pandemic has profoundly exacerbated pre-existing gender inequalities. Women are being forced out of the labour market in higher numbers than men, whilst they are also bearing the brunt of homeschooling, as well as increased unpaid care and domestic work. Incidents of domestic violence have soared during lockdown. Moreover, for women whose immigration status is linked to that of their partner this significantly decreases the likelihood that they will leave an unsafe home. See e.g. https://voxeu.org/article/covid-19-and-gender-gaps-latest-evidence-and-lessons-uk; and https://www.unwomen.org/en/news/stories/2020/4/statement-ed-phumzile-violence-againstwomen-during-pandemic (accessed 14 February 2021).

16. See e.g. https://www.ft.com/content/6c7b59ad-be4f-46b3-8386-072f106a1960; https://www.ft.com/ content/2b34269a-73f8-11ea-95fe-fcd274e920ca; and https://www.ft.com/content/d31e6627-1cc34f10-b96e-2b9e2670aaac (accessed 14 February 2021).

17. See e.g. https://www.bbc.co.uk/news/uk-52342511 and https://www.bbc.co.uk/news/uk-52169648 (accessed 14 February 2021).

18. See https://www.theguardian.com/society/2020/may/26/care-workers-should-be-better-paid-andvalued-after-covid-19-poll (accessed 14 February 2021).

19. https:/yougov.co.uk/topics/consumer/articles-reports/2020/06/01/do-key-workers-feel-appreciated-work-during-covid- (accessed 14 February 2021).

20. https://www.thelondoneconomic.com/politics/sunak-told-not-to-grind-frontline-workers-downafter-a-decade-of-pay-austerity/23/11/ (accessed 14 February 2021).

21. See https://www.theguardian.com/politics/2020/mar/29/20000-nhs-staff-return-to-service-johnson-says-from-coronavirus-isolation (accessed 14 February 2021).

22. See https://www.gov.uk/government/speeches/pm-address-to-the-nation-on-coronavirus-10-may-2020 (emphasis added) (accessed 14 February 2021). 
23. https://www.gov.uk/government/speeches/pm-address-to-the-nation-on-coronavirus23-march-2020 (accessed 14 February 2021).

24. This kind of everyday bordering has affected many groups among the British population, and particularly individuals in the asylum system and migrants with precarious status (see Meier and Doná 2021). However, these practices have also affected long-term residents, most notably the Windrush generation of Caribbean migrants who arrived in the UK between 1948 and 1973; see: https://www.theguardian.com/uk-news/2019/jun/27/home-office-windrush-report-damns-hostileenvironment-policy (accessed 14 February 2021).

25. https://blogs.lse.ac.uk/politicsandpolicy/covid19-mutual-aid-solidarity/ (accessed 14 February 2021).

26. https://covidmutualaid.org/ (accessed 14 February 2021).

27. See e.g. https://www.independent.co.uk/news/uk/home-news/coronavirus-home-office-deportations-un-immigration-removals-a9560606.html (accessed 14 February 2021)

28. https://www.opendemocracy.net/en/opendemocracyuk/exclusive-most-support-uk-citizenshipmigrant-frontline-workers/ (accessed 14 February 2021).

29. For grassroots campaigns against these charges, see http://www.docsnotcops.co.uk.

30. https://www.gov.uk/government/publications/uk-points-based-immigration-system-employerinformation/the-uks-points-based-immigration-system-an-introduction-for-employers (accessed 14 February 2021).

31. https://metro.co.uk/2020/10/16/doctor-paralysed-after-catching-covid-could-see-family-deported-while-still-in-icu-13431926/ (accessed 14 February 2021).

32. Of course, the intensification of everyday bordering and the xenophobic implications of Brexit are one aspect of the pandemic's racist inflections. Both frontline BAME workers and ethnic minorities more generally have also have died in disproportionate numbers during the pandemic, mostly due to unsafe working and housing conditions. See https://theconversation.com/49-more-likely-to-die-racial-inequalities-of-covid-19-laid-bare-in-study-of-east-london-hospitals-153834 (accessed 14 February 2021).

33. https://ajph.aphapublications.org/doi/pdfplus/10.2105/AJPH.2020.305766 (accessed 14 February 2021).

34. See e.g. https://www.theguardian.com/commentisfree/2020/may/27/healthcare-workers-heros-language-heroism; and https://www.theguardian.com/commentisfree/2020/apr/23/uk-key-workers-ppeministers-clapping-protect-nhs (accessed 14 February 2021).

35. https://www.theguardian.com/society/2020/may/21/nhs-doctor-enough-people-clapping?utm_source=dlvr. it\&utm_medium=facebook\&fbclid=IwAR1esIQL_G8ARU9nyHmFS9pYXwmKJ8ubmnX-HDY9INkE_ AkV-Z7zj5BC6Yw (accessed 14 February 2021).

36. https://www.theguardian.com/society/2021/jan/13/nhs-icu-staff-ptsd-severe-depression-anxiety (accessed 14 February 2021).

37. See https://www.theguardian.com/society/2021/jan/20/neil-greenberg-hospitals-must-give-staffbetter-psychological-ppe-covid; and https://www.bbc.co.uk/news/health-55630157 (accessed 14 February 2021).

38. See https://www.nhsggc.org.uk/your-health/health-issues/covid-19-coronavirus/life-on-the-frontline/; https://www.berkshirehealthcare.nhs.uk/covid-19-coronavirus/life-on-the-front-line/nhs-staff-stories/; and https://www.kentcht.nhs.uk/2020/08/13/on-the-frontline-during-covid-19/ (accessed 14 February 2021).

39. https://www.england.nhs.uk/2020/04/student-docs-and-nurses-praised-for-joining-nhs-army-totackle-historic-coronavirus-threat/ (accessed 14 February 2021).

40. Studies on tracking apps found that mobility within cities fell much less during the second and third lockdown as compared to the first. This has raised concerns that people were no longer following the COVID-19 restrictions in the same way as they had been in March 2020. 


\section{References}

Ahmed, S. (2010) The Promise of Happiness. Durham, NC: Duke University Press.

Anderson, B. (1991 [1983]). Imagined Communities: Reflections on the Origin and Spread of Nationalism. London: Verso.

Balogun, J., Best, K. and Lê, J. (2015) "Selling the Object of Strategy: How Frontline Workers Realize Strategy through their Daily Work", Organization Studies, 36(10): 1285-1313.

Bell, C. (2012) "War and the Allegory of Medical Intervention: Why Metaphors Matter", International Political Sociology, 6(3): 325-8.

Bergfeld, M. and Farris S. (2020) "The COVID-19 Crisis and the End of the 'Low-Skilled' Worker", Spectre Journal. Available at: https://spectrejournal.com/the-covid-19-crisis-and-the-end-of-thelow-skilled-worker/ (accessed 4 February 2021).

Bowleg, L. (2020) "We're Not All in This Together: On COVID-19, Intersectionality, and Structural Inequality", American Journal of Public Health, 110(7): 917-18.

Brown, W. (2015) Undoing the Demos: Neoliberalism's Stealth Revolution. Boston: MIT Press.

Brown, W. (2019) In the Ruins of Neoliberalism: The Rise of Antidemocratic Politics in the West. New York: Columbia University Press.

Butler, J. (1990) Gender Trouble: Feminism and the Subversion of Identity. London: Routledge.

Butler, J. (1993) Bodies that Matter: On the Discursive Limits of Sex. London: Routledge.

Butler, J. (1997) Excitable Speech: A Politics of the Performative. London: Routledge.

Butler, J. (2009) Frames of War: When is Life Grievable? London: Verso.

Dardot, P. and Laval, C. (2014) The New Way of the World: On Neoliberal Society. London: Verso.

De Camargo, C. and Whiley, L. (2020) "The Mythologisation of Key Workers: Occupational Prestige Gained, Sustained ... and Lost?”, International Journal of Sociology and Social Policy, 40(9-10): $849-59$.

Essed, P. (2008) “Everyday Racism”, in D. Goldberg and J. Solomos, eds., A Companion to Racial and Ethnic Studies. London: John Wiley \& Sons, 202-16.

Financial Times (2020) "Virus Lays Bare the Frailty of the Social Contract", 3 April. Available online at: https://www.ft.com/content/7eff769a-74dd-11ea-95fe-fcd274e920ca (accessed 14 February 2021).

Fotherby, J. (2020) “The 'Invisible Enemy': A Critical Look at the Use of Military Metaphors and Aanthropomorphisation during the COVID-19 Pandemic", Medical Anthropology at UCL. Available online at https://medanthucl.com/2020/05/13/the-invisible-enemy-a-critical-look-at-the-use-of-militarymetaphors-and-anthropomorphisation-during-the-covid-19-pandemic/ (accessed 14 February 2021).

Foucault, M. (2008) The Birth of Biopolitics: Lectures at the College de France, 1978-1979. London: Springer.

Gardner, Z. (2020) "Punishing Migrants: Stubborn Home Office COVID Response Puts Everyone at Risk", Politics.co.uk, 9 April. Available online at: https://www.politics.co.uk/comment-analysis/2020/04/09/ punishing-migrants-stubborn-home-office-covid-response-puts (accessed 14 February 2021).

Good Law Project (2020) Available online at: https://goodlawproject.org/ (accessed 14 February 2021).

Gordon, N. (2021) "Between the Norm and the Law: On the Limits of Legal Advocacy When Protecting Medical Units during War", in B. Jehan, M. Hofman and J. Whittall, eds., Everybody's War: The Politics of Aid in the Syrian Crisis. London: Oxford University Press.

Gordon, N. and Green, P. (2021) "State Crime, Structural Violence and COVID-19", State Crime, 10(1): 4-15.

Green, P. and Ward, T. (2004) State Crime: Governments, Violence and Corruption. London: Pluto Press. 
Gunaratnam, Y. (2020) "Reimagining the Frontline from Heaven's Edge", New Politics, 6 May. Available online at: https://newpol.org/reimagining-the-frontline-from-heavens-edge (accessed 4 February 2021).

Jones, C. (2001) "Voices from the Front Line: State Social Workers and New Labour", British Journal of Social Work, 31(4): 547-62.

Lakoff, G. and Johnson, M. (2008) Metaphors we Live by. Chicago: University of Chicago Press.

Meier, I. and Doná, G. (2021) "The Politics of Time: Asylum Regimes, Temporalities and Power", in M. Bhatia and V. Canning, eds., Stealing Time: Migration, Temporalities and State Violence. Basingstoke: Palgrave.

Poole, S. (2020) “'Frontline': Is it Misleading to Apply Military Metaphors to Medicine?", The Guardian, 16 April. Available online at: https://www.theguardian.com/books/2020/apr/16/frontline-is-it-misleading-to-apply-military-metaphors-to-medicine (accessed 4 February 2021).

Rosenthal, P. (2004) "Management Control as an Employee Resource: The Case of Front-Line Service Workers", Journal of Management Studies, 41(4): 601-22.

Saad Filho, A. (2020) "From COVID-19 to the End of Neoliberalism", Critical Sociology, 46(4-5): $477-85$.

Schmitt, C, (2005) Political Theology: Four Chapters on the Concept of Sovereignty. Chicago: University of Chicago Press.

Semino, E. (2021) “Not Soldiers But Fire-Fighters: Metaphors and Covid-19”, Health Communication, 36(1): $50-8$.

Sontag, S. (2001 [1978]) Illness as Metaphor and AIDS and its Metaphors. London: Macmillan.

Steward, I. (2021) "A Shifting Consensus on Economic Policy: A View from London", Deloitte Insights. Available online at: https://www2.deloitte.com/us/en/insights/economy/emea/a-viewfrom-london.html (accessed 14 February 2021).

Wood, H. and Skeggs, B. (2020) "Clap for Carers? From Care Gratitude to Care Justice", European Journal of Cultural Studies, 23(4): 641-7.

Yuval-Davis, N., Wemyss, G. and Cassidy, K. (2019). Bordering. London: Polity. 